\title{
Penerapan Extreme Programming Pada Sistem Informasi Pembayaran Sumbangan Pembinaan Pendidikan (SPP)
}

\author{
Arief Rusman $^{1}$, Siti Lutfiyah Angraini ${ }^{2}$ \\ ${ }^{1}$ STMIK Nusa Mandiri/Sistem Informasi \\ e-mail: arief.aef@nusamandiri.ac.id \\ ${ }^{2}$ Universitas Bina Sarana Informatika/Sistem Informasi \\ e-mail: sitilutfiyah5@gmail.com
}

Cara Sitasi: Rusman, A., \& Angraini, S. L. (2019, Maret). Penerapan Extreme Programming Pada Sistem Informasi Pembayaran Sumbangan Pembinaan Pendidikan (SPP). (S. Dalis, Ed.) Paradigma - Jurnal Komputer dan Informatika, 21(1), 17-22. doi:10.31294/p.v21i1.4631

\begin{abstract}
The use of information and communication technology is one of the technological developments that can provide benefits in the field of education such as in the management of school payments. The school payment process requires fast and accurate data processing in terms of payment and storage until report generation. The purpose of this research is to make a school payment information system that is fast and accurate in its processing. With extreme programming method is expected to help resolve existing problems. The expected results will be an information system that can help the payment process in the school that is able to process payment data quickly and accurately to produce a payment data that can be used as a guideline for decision making by the school head masters. The expected form of report can also be more easily understood than before using an information system. In the process of storing data it is also expected to be better because it does not use paper but can already be stored in a database system that is connected to an information system.
\end{abstract}

Keywords: Informations System, Extreme Programming, School Payment

\section{PENDAHULUAN}

Perkembangan teknologi komputer sudah merambat ke dunia pendidikan, hampir seluruh sekolah sudah memiliki teknologi komputer dalam mengelola data sekolah, seperti absensi karyawan dan guru, data penggajian serta pengolahan data keuangan. Dalam penyajian informasi setiap sekolah mempunyai cara yang berbeda-beda, ada yang sudah terkomputerisasi dan ada juga yang masih manual. Proses mengelola keuangan sekolah seperti Pembayaran Sumbangan Pembinaan Pendidikan (SPP) yang dikelola pada SMP Assalafy masih manual dengan menggunakan kartu bayar untuk dicatatkan dalam setiap pembayaran SPP per siswanya. Permasalahan yang sering terjadi pada proses pembayaran SPP tersebut adalah hilangnya kartu bayar pada siswa, laporan keuangan yang sangat banyak sehingga sulit dicari jika dibutuhkan, terlambatnya pemberitahuan jika ada siswa yang belum membayar SPP. Karena dasar itulah dibutuhkan sebuah sistem informasi yang dapat mengolah data pembayaran SPP. "Penggunaan sistem informasi yang baik dapat membantu proses pembayaran yang dilakukan oleh setiap siswa"(Rusman \& Ramanda, 2018). "Sistem informasi sangat bisa dihandalkan untuk memecahkan berbagai masalah yang terjadi pada seseorang maupun perusahaan yang bergerak di bidang barang maupun jasa. Dimana Sistem informasi menjadi alat bantu yang efektif untuk melayani permintaan data"(Ramanda, 2017).

\section{METODOLOGI PENELITIAN}

\section{Extreme Programming}

"Extreme Programming (XP) dikenal dengan metode technical how to atau bagaimana suatu tim teknis mengembangkan perangkat lunak secara efisien melalui berbagai prinsip dan teknik praktis pengembangan perangkat lunak. XP menjadi dasar bagaimana tim bekerja sehari-hari"(Ferdiana, 2012). Global Extreme Programming yaitu pengembangan dari XP (Extreme Programming) Life Cycle, dalam Global Extreme Programming terdapat lima fase yaitu Exploration, Planning, Iteration, Production dan Maintenance.

\section{a. Exploration phase (Fase eksplorasi)}

Fase eksplorasi memfokuskan pada pengambilan kebutuhan klien. Pada tahap ini visi produk dan tujuan bisnis aplikasi dirumuskan dan diatur 
kembali. Hasil dari tahap ini adalah sekumpulan kebutuhan pengguna beserta prototipe yang ditunjukkan untuk tahap berikutnya.

\section{b. Planning phase (Fase Perencanaan)}

Fase perencanaan memfokuskan pada pemilihan kebutuhan yang sesuai dengan batasan-batasan yang dimiliki klien dan tim. Kesepakatan fase ini menghasilkan rencana rilis dan rencana iterasi. Rencana rilis adalah melampirkan fitur-fitur yang akan dikembangkan dalam jangka waktu yang telah disepakati. Rencana iterasi menghasilkan sekumpulan tahapan-tahapan yang akan dilakukan beserta keluaran yang diperoleh untuk setiap tahapan.

\section{c. Iteration Phase (Fase Iterasi)}

Fase ini dikenal juga dengan fase pengembangan solusi. Fase iterasi adalah melakuan eksekusi perencanaan iterasi melalui serangkaian aktivitas teknis seperti pembuatan arsitektur, pembuatan kode, dan melakukan unit test untuk setiap modul. Hasil keluaran setiap iterasi dikenal dengan rilis parsial/small release.

\section{d. Production Phase (Fase Produksi)}

Fase ini melakukan pengujian terhadap hasil setiap iterasi. Tim akan melakukan pengujian dengan melibatkan klien. Pada tahapan ini dilakukan juga verifikasi dan integrasi terhadap hasil dengan rencana rilis yang ada. Hasil fase ini adalah sebuah solusi yang sudah dites baik oleh tim dan klien.

\section{e. Maintenance Phase (Fase Pemeliharaan)}

Fase ini memfokuskan pada layanan didukung setelah software tersebut dikembangkan. Fase ini melakukan perbaikan kesalahan pada solusi dan penyesuaian kecil pada solusi. Pada fase ini dimungkinkan pula terjadi kesepakatan untuk pengembangan sistem pada rilis selanjutnya.

\section{Pengertian Sistem}

"Sistem adalah kumpulan dari elemenelemen yang berinteraksi untuk mencapai suatu tujuan tertentu"(Mustakini, 2005). Pendekatan sistem yang merupakan jaringan kerja dari prosedur yang lebih menekankan urutan-urutan operasi. Suatu prosedur adalah suatu urutan-urutan yang tepat dari tahapantahapan instruksi yang menerangkan apa (what) yang harus dikerjakan, siapa (who) yang mengerjakan, kapan (when) dikerjakan dan bagaimana (how) mengerjakannya.

Suatu sistem mempunyai karakteristik atau sifat-sifat tertentu, yaitu sebagai berikut :

a. Komponen sistem, suatu sistem terdiri dari sejumlah komponen yang saling berinteraksi, artinya saling bekerja sama membentuk suatu kesatuan. Komponen-komponen sistem dapat berupa suatu subsistem atau bagian-bagian dari sistem.

b. Batasan sistem, merupakan daerah yang membatasi antara suatu sistem dengan sistem yang lainnya atau dengan lingkungan luarnya. Batas suatu sistem menunjukan ruang lingkup dari sistem tersebut.

c. Lingkungan luar sistem, adalah apapun diluar batas dari sistem yang mempengaruhi operasi sistem. Lingkungan luar dapat bersifat menguntungkan dan juga merugikan. Lingkungan luar yang menguntungkan berupa energi dari sistem dan dengan demikian harus dijaga dan dipelihara. Sedangkan yang merugikan harus ditahan dan dikendalikan, jika tidak maka akan mengganggu kelangsungan hidup dari sistem.

d. Penghubung sistem, merupakan media yang menghubungkan antara satu subsistem dengan subsistem yang lainnya. Keluaran dari satu subsistem akan menjadi masukan bagi subsistem lainnya melalui penghubung sistem ini.

e. Masukan sistem, adalah energi yang dimasukan kedalam sistem. Masukan dapat berupa masukan perawatan dan masukan sinyal. Masukan perawatan adalah energi yang dimasukan agar sistem tersebut dapat berjalan. Masukan sinyal adalah energi yang diperoses untuk mendapatkan keluaran dari sistem.

f. Keluaran Sistem, adalah energi yang diolah dan diklasifikasikan menjadi keluaran yang berguna. Keluaran dapat berupa masukan untuk subsistem yang lain.

g. Pengolahan sistem, suatu sistem dapat mempunyai suatu bagian pengolahan atau sistem itu sendiri sebagai pengolahanya. Pengolah yang akan merubah masukan menjadi keluaran.

h. Sasaran sistem, setiap sistem pasti mempunyai tujuan atau sasaran. Suatu sistem dikatakan berhasil jika mengenai sasarannya. Sasaran sangat berpengaruh pada masukan dan keluaran yang dihasilkan system.(Ladjamudin, 2013).

\section{Pengertian Informasi}

"Informasi adalah data yang telah diolah menjadi bentuk yang lebih berarti bagi yang penerimanya"(Mustakini, 2005). Data merupakan bentuk yang masih mentah yang belum dapat bercerita banyak, sehingga perlu diolah lebih lanjut. Data diolah suatu model untuk dihasilkan menjadi informasi.

\section{Pengertian Sistem Informasi}

"Sistem informasi adalah suatu sistem di dalam suatu organisasi yang mempertemukan kebutuhan pengolahan transaksi harian yang mendukung fungsi operasi organisasi yang bersifat manajerial dengan kegiatan strategi dari suatu organisasi untuk dapat 
menyediakan kepada pihak luar tertentu dengan laporan-laporan yang diperlukan"(Sutabri, 2012).

\section{Agile Software Development}

"Proses ini ditandai dengan model yang dikenal dengan interaktif dan inkremental. Proses yang meyakini bahwa suatu perangkat lunak dapat dikembangkan dengan desain minimalis, pengujian bertahap, dan dokumentasi yang tidak berlebihan"(Ferdiana, 2012). "Agile Software Development adalah sebuah metode dalam pengembangan atau pembuatan sistem dengan cara cepat, artinya kebutuhan sistem sudah terpenuhi dengan melibatkan client dalam pembuatan softwarenya, sehingga kemungkinan sistem gagal itu sangat sedikit".(Lubis, 2016)

\section{UML (Unified Modeling Language)}

"UML (Unified Modeling Language) adalah Keluarga notasi grafis yang didukung oleh metamodel tunggal, yang membantu pendeskripsian dan desain sistem perangkat lunak, khususnya sistem yang dibangun menggunakan pemrograman berorientansi objek. Definisi ini merupakan definisi yang sederhana"(Fowler, 2005)

\section{ERD (Entity Relationship Diagram)}

"ERD dikembangkan berdasarkan teori himpunan dalam bidang matematika. ERD digunakan untuk pemodelan basis data relasional. Sehingga jika penyimpanan basis data menggunakan OODBMS maka perancangan data tidak perlu menggunakan ERD”. (Sukamto \& Shalahuddin, 2013)

\section{HASIL DAN PEMBAHASAN}

1. Fase Eksplorasi

Pada fase ini, penulis merangkum kebutuhan pengguna sebagai berikut :

a. Bagian tata usaha dapat mengelola data siswa

b. Bagian tata usaha dapat mengelola data user

c. Bagian tata usaha dapat mengelola data pembayaran

d. Bagian tata usaha dapat membuat laporan pembayaran

e. Bagian tata usaha dapat membuat laporan tunggakan

2. Fase Perencanaan

Pada fase ini, digambarkan dengan unified modeling language dan entity relationship diagram

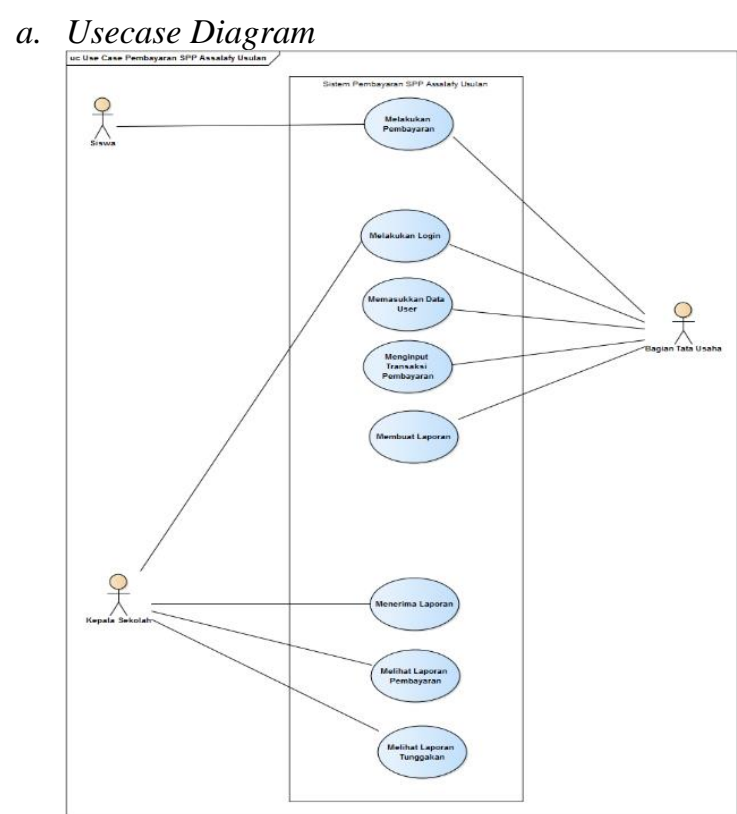

Sumber : Penelitian (2018)

Gambar 1. Usecase Diagram Sistem Pembayaran SPP

b. Entity Relationship Diagram

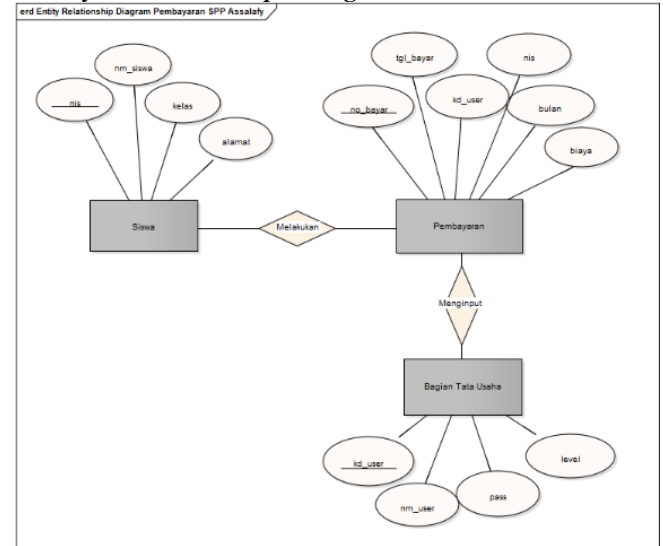

Sumber : Penelitian (2018)

Gambar 2. Entity Relationship Diagram Sistem Pembayaran SPP

c. Logical Record Structure

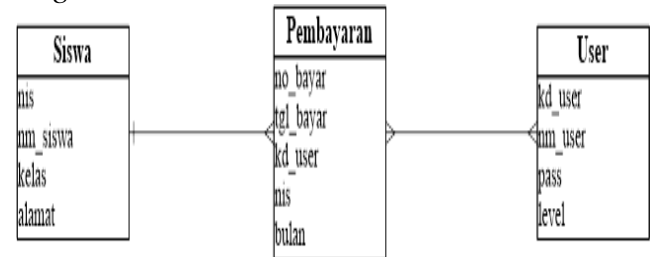

Sumber : Penelitian (2018)

Gambar 3. Logical Record Structure Sistem Pembayaran SPP

3. Fase Iterasi 
Pada fase ini, mulai merancang alur dan jalannya sistem informasi

a. Activity Diagram

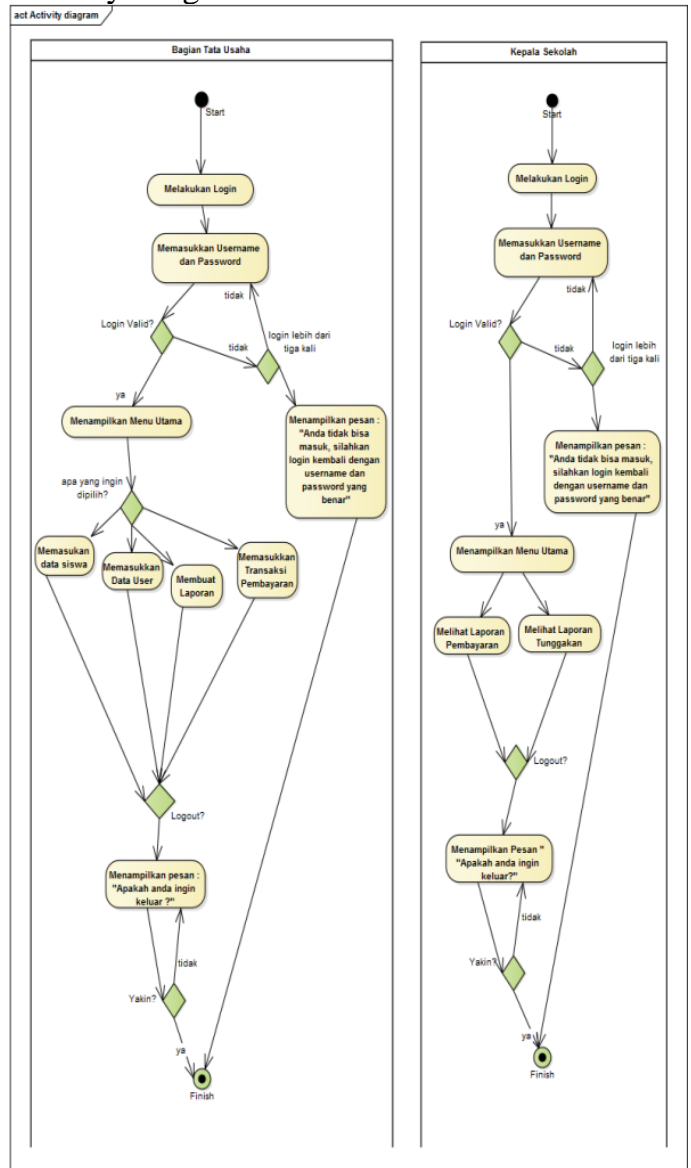

Sumber : Penelitian (2018)

Gambar 4. Activity Diagram Sistem Pembayaran SPP

b. Class Diagram

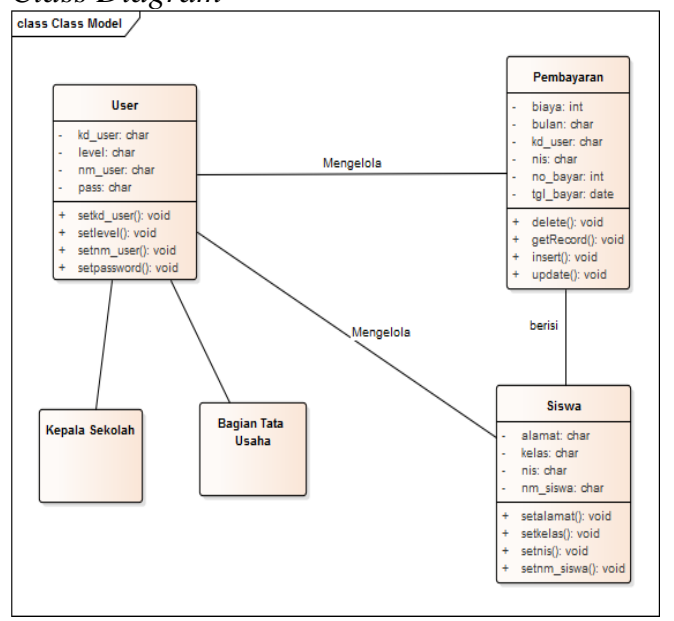

Sumber : Penelitian (2018)

Gambar 5. Class Diagram Sistem Pembayaran SPP
4. Fase Produksi

Pada fase ini, mulai dibentuk aplikasi sesuai dengan rancangan sebelumnya

a. Sequence Diagram

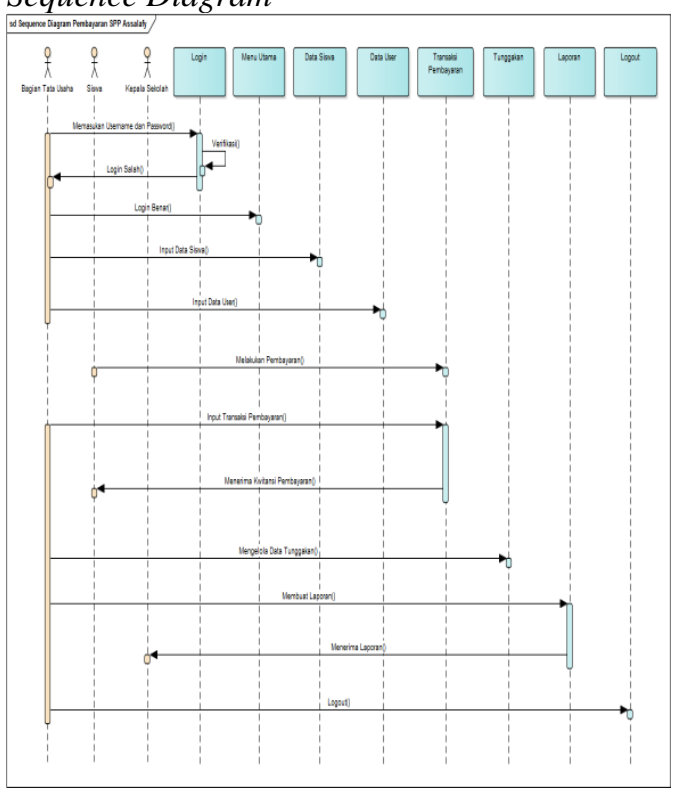

Sumber : Penelitian (2018)

Gambar 6. Sequence Diagram Sistem Pembayaran SPP

b. Spesifikasi File

Tabel 1. Spesifikasi file siswa

\begin{tabular}{ccccc}
\hline Elemen Data & Nama Field & Tipe & Size & Ket \\
\hline NIS & nis & Text & 7 & PK \\
Nama Siswa & nm_siswa & Text & 30 & \\
Kelas & Kelas & Text & 5 & \\
Alamat & Alamat & Text & 25 &
\end{tabular}

Sumber : Penelitian (2018)

Tabel 2. Spesifikasi file user

\begin{tabular}{ccccc}
\hline Elemen Data & Nama Field & Tipe & Size & Ket \\
\hline Kode user & kd_user & Text & 8 & PK \\
Nama & nm_user & Text & 30 & \\
Password & pass & Text & 10 & \\
Akses Level & level & Text & 5 & \\
\hline
\end{tabular}

Sumber : Penelitian (2018)

Tabel 3. Spesifikasi file pembayaran

\begin{tabular}{ccccc}
\hline Elemen Data & Nama Field & Tipe & Size & Ket \\
\hline No Bayar & no_bayar & Number & 10 & PK \\
Tgl Bayar & tgl_bayar & Date & & \\
Kode User & kd_user & Text & 8 & FK \\
NIS & nis & Text & 7 & FK
\end{tabular}




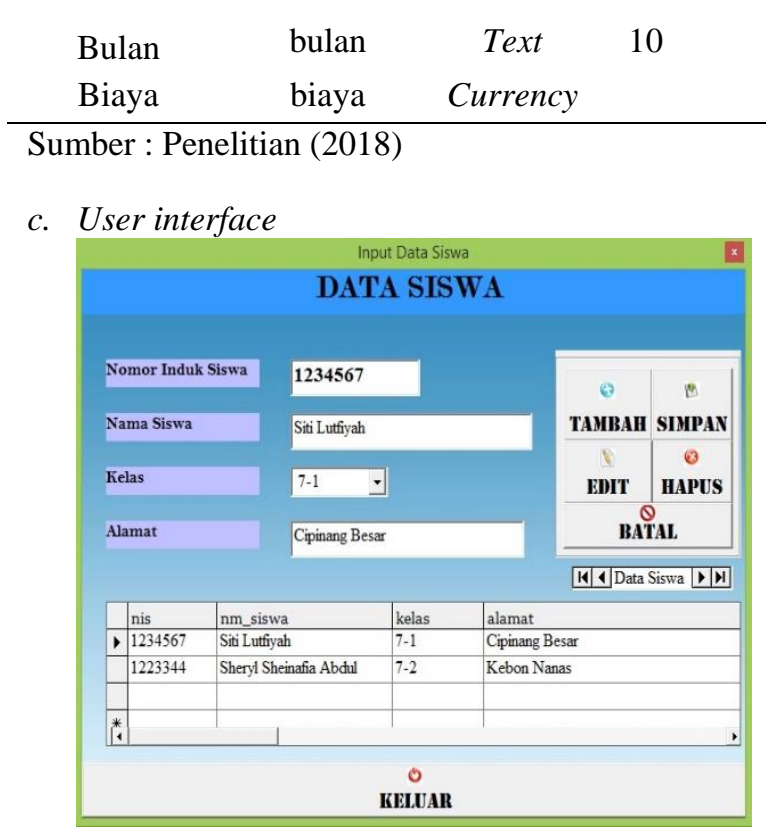

Sumber : Penelitian (2018)

Gambar 7. User interface data siswa

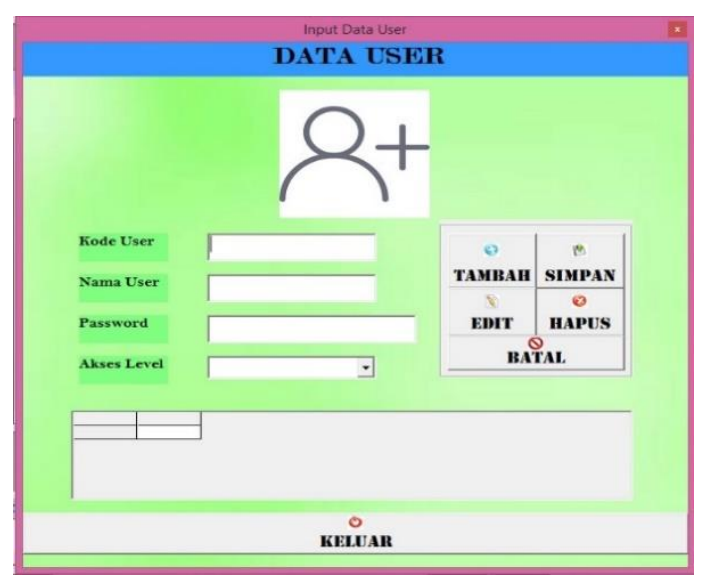

Sumber : Penelitian (2018)

Gambar 8. User interface data user

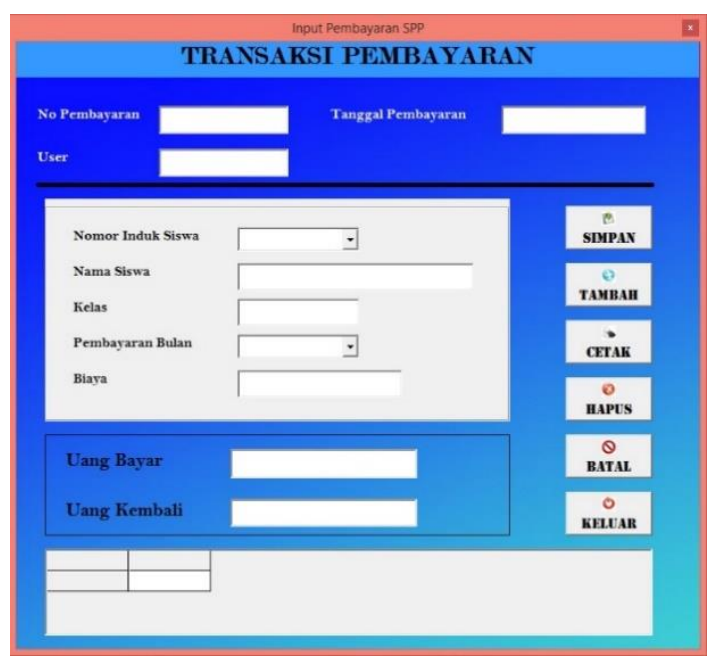

Sumber : Penelitian (2018)

Gambar 9. User interface transaksi pembayaran

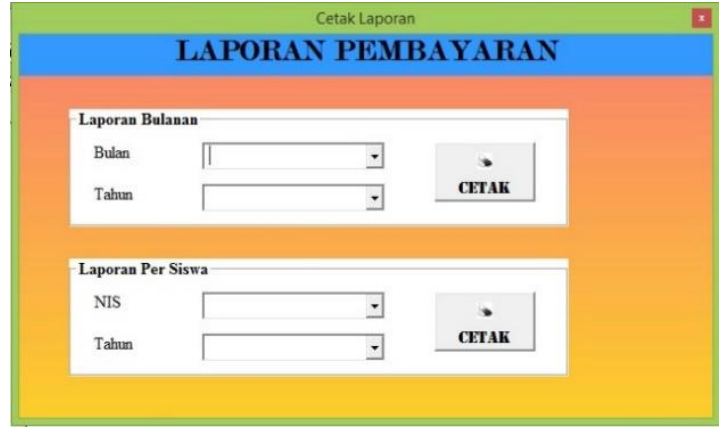

Sumber : Penelitian (2018)

Gambar 10. User interface laporan pembayaran

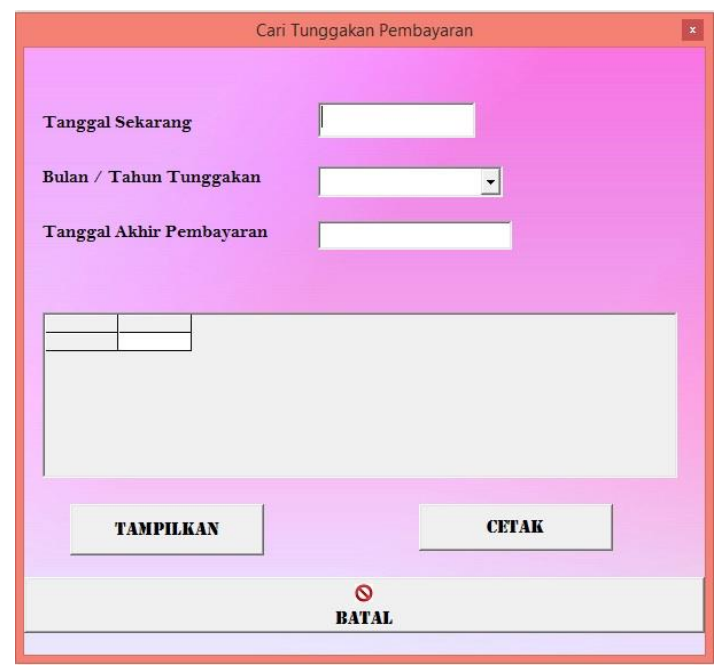

Sumber : Penelitian (2018)

Gambar 11. User interface laporan tunggakan pembayaran

\section{KESIMPULAN}

Berdasarkan hasil penelitian dan pembahasan sebelumnya, kesimpulan yang dapat ditarik dalam perancangan sistem informasi pembayaran SPP adalah sebagai berikut

1. Sistem pembayaran SPP secara terkomputerisasi dapat menangani proses pembayaran SPP secara lebih cepat dan akurat sehingga dapat membantu dalam pengolahan data yang lebih baik daripada memakai sistem yang lama masih manual.

2. Penggunaan sistem yang terkomputerisasi dapat mempermudah proses pembayaran SPP serta dalam hal pembuatan laporan.

3. Data yang berhubungan dengan sistem pembayaran SPP tersimpan dalam bentuk database secara terkomputerisasi dapat melakukan pengubahan data, penghapusan data, pencarian data dan penyimpanan data lebih mudah dan tersimpan secara rapi. 


\section{REFERENSI}

Ferdiana, R. (2012). Rekayasa Perangkat Lunak yang Dinamis dengan Global Extreme Programming. Yogyakarta: Andi.

Fowler, M. (2005). UML Distilled 3th Panduan Singkat Bahasa Pemodelan Berorientasi Objek Standar. Yogyakarta: Andi Ofset.

Ladjamudin, A.-B. (2013). Analisis dan Desain Sistem Informasi. Yogyakarta: Graha Ilmu.

Lubis, B. O. (2016). Penerapan Global Extreme Programming Pada Sistem Informasi Workshop, Seminar Dan Pelatihan Di Lembaga Edukasi. Jurnal Informatika, 3(2), 234-246. Retrieved from http://ejournal.bsi.ac.id/ejurnal/index.php/ji/art icle/view/1055

Mustakini, J. H. (2005). Analisis \& Desain Sistem Informasi. Yogyakarta: Andi.

Ramanda, K. (2017). Sistem Informasi Manajemen Proyek Berbasis Web. Indonesian Journal on Networking and Security, 6(4), 14-17.

Rusman, A., \& Ramanda, K. (2018). Penerapan Global Extreme Programming Pada Sistem Informasi Pembayaran Angsuran Bimbingan
Belajar. In SEMNAS IKRA-ITH (pp. 72-81). Jakarta: LPPM Universitas Persada Indonesia Y.A.I.

Sukamto, R. A., \& Shalahuddin, M. (2013). Rekayasa perangkat lunak terstruktur dan berorientasi objek. Bandung: Informatika.

Sutabri, T. (2012). Analisa Sistem Informasi. Yogyakarta: Andi.

\section{PROFIL PENULIS}

Arief Rusman lahir di Jakarta pada tanggal 12 November 1989. Menyelesaikan studi Strata 1 pada tahun 2012 di STMIK Nusa Mandiri Jakarta program studi Sistem Informasi dan Strata 2 pada tahun 2015 di Pascasarjana STMIK Nusa Mandiri Jakarta program studi E-Business.

Siti Lutfiyah Anggraini lahir di Jakarta pada tanggal 21 November 1997. Menyelesaikan studi Diploma 3 pada tahun 2018 di Universitas Bina Sarana Informatika program studi Sistem Informasi. 